\title{
Funkcjonowanie i rozbudowa Elektrowni Opole w opiniach mieszkańców gminy Dobrzeń Wielki ${ }^{1}$
}

\section{Abstract \\ Operation and Development of the Opole Power Plant in the Opinions of the Residents of the Dobrzen Wielki Commune}

The article discusses the social reception of various phenomena occurring in the Dobrzen Wielki commune accompanying the operation and development of a major industrial investment: the Opole powerstation. The subject matter concerns the course of fieldwork aimed at identifying socioeconomic processes and the attitudes of people living in the area affected by those processes. The author's main focus is the question of interactions between the powerstation and the local community, as well as the social reception of related phenomena.

Keywords: local community, local economics, large industrial investment, social conflict and cooperation.

Wśród badaczy specjalizujących się w antropologii ekonomicznej można spotkać się ze stwierdzeniem, które w istotny sposób opisuje fundamentalny problem w podejmowaniu badań gospodarki i ekonomii przez badaczy kultury. Twierdzą oni na przykład, że „podstawowe dylematy dotyczące definicji gospodarki oraz

1 Artykuł powstał w ramach grantu badawczego pod tytułem Konflikt, napięcie, wspótpraca. Studium interakcji pomiędzy Elektrownią Opole a społecznością gminy Dobrzeń Wielki finansowanego przez Narodowe Centrum Nauki (nr DEC-2013/11/B/HS3/03895). 
teorii i metod, których antropolodzy powinni użyć, żeby ją badać, nigdy nie zostały rozwiązane” (Hann, Hart 2015: 186). Podkreśla się również, że „dla antropologów ekonomicznych istotne jest to, by ich lokalna wiedza została usytuowana w szerszym kontekście historycznym" (Hann, Hart 2015: 192). Uzyskanie takiego szerszego obrazu lokalnych ekonomii możliwe jest dzięki badaniom etnograficznym prowadzonym w określonych środowiskach społeczno-kulturowych, w których granice życia społecznego obejmującego stosunki ekonomiczne są zazwyczaj ściśle określone i wydają się możliwe do uchwycenia. Podejmowanie określonych strategii ekonomicznych jest w dużym stopniu efektem obserwacji zachodzących na danym terenie zjawisk, które nieustannie podlegają ocenom i mają wpływ na decyzje o podjęciu lub zaniechaniu konkretnych działań. Opinie na temat zmian warunkują zatem stopień zaangażowania i $\mathrm{z}$ tego powodu ich badanie powinno poprzedzać analizę przedsięwzięć, $\mathrm{w}$ tym wypadku mających charakter ekonomiczny. Próbę przedstawienia takiego typu postaw i opinii w środowisku lokalnym stanowi prezentowany tekst. Oparty jest on na badaniach podstawowych prowadzonych na Opolszczyźnie w gminie Dobrzeń Wielki, gdzie ulokowana została jedna $\mathrm{z}$ największych elektrowni węglowych w Polsce, która obecnie jest rozbudowywana. Różnorakie procesy związane z tym faktem były tematem badań terenowych. Jeden $z$ ich kluczowych elementów dotyczył wzajemnych relacji pomiędzy szeroko rozumianą społecznością lokalną a wielką inwestycją przemysłową ${ }^{2}$. Efekty takich badań stanowią zatem studium przypadku dostarczające istotnych danych, które mogą umożliwić w przyszłości pogłębioną analizę porównawczą oraz pozwolić na dokonanie uogólnień o charakterze teoretycznym.

Eksploracja i analiza wielowymiarowych i powiązanych $\mathrm{z}$ sobą procesów kulturowych, społecznych i politycznych, będących kontekstem, a zarazem rezultatem interakcji pomiędzy PGE Elektrownią Opole SA a społecznością gminy Dobrzeń Wielki, dotyczy w dużej mierze problemów natury ekonomicznej. Uległy one intensyfikacji wraz z realizacją rozbudowy elektrowni, która obecnie jest jednym z największych przedsięwzięć w europejskiej energetyce. Podejmując próbę identyfikacji zachodzących na badanym obszarze procesów społeczno-ekonomicznych, należy zwrócić uwagę na postawy ludności zamieszkującej strefę, której procesy te dotykają. Obejmują one różnego rodzaju zjawiska i powiązania pomiędzy nimi, ukierunkowane między innymi na działalność gospodarczą. W grę wchodzą zatem rozmaite formy strategii ekonomicznych, od tych oddolnych, takich jak na przykład jednoosobowe działalności gospodarcze, poprzez większe firmy zatrudniające od kilku do kilkunastu czy kilkudziesięciu osób, po duże przedsiębiorstwa rozlokowane głównie w sąsiedztwie Elektrowni Opole. Sama elektrownia stanowi tu najważniejszy punkt odniesienia, jako główny gracz, który jest motorem napędowym działań podejmowanych w ramach lokalnej, ale

2 Artykuł przedstawia tylko fragment efektów badań, które obejmowały również takie zagadnienia, jak polityka lokalna, strategie ekonomiczne, migracje czy kwestie narodowościowe. Stąd też tekst powinien być odczytywany jako część większej całości. 
także ponadlokalnej ekonomii. Dodać należy, że badania na ten temat ukierunkowane zostały głównie na uzyskanie wiedzy dotyczącej społecznego odbioru tych wszystkich przedsięwzięć, które wpisały się w ogólny temat prowadzonych badań, czyli odnosiły się do interakcji pomiędzy elektrownią, konkretnie jej rozbudową, a społecznością lokalną. Aby jednak zidentyfikować to, jak mieszkańcy i przedsiębiorcy działający na terenie gminy opisują i oceniają praktyki społeczne o charakterze ekonomicznym, należało się zapoznać - na tyle, na ile jest to możliwe $-\mathrm{z}$ rejestrami firm, które dają ogólną wiedzę na temat liczby i charakteru podejmowanych na terenie gminy przedsięwzięć gospodarczych. Posiadając wiedzę głównie o charakterze ilościowym, można przystąpić do badań jakościowych, czyli przeprowadzić pogłębione wywiady $\mathrm{z}$ wybranymi przedstawicielami miejscowej społeczności. Wywiady te często $\mathrm{z}$ kwestionariuszowych przeradzają się $\mathrm{w}$ długie rozmowy, w trakcie których poruszane są rozmaite problemy nurtujące mieszkańców i przedsiębiorców, mniej czy bardziej związanych z rozbudową elektrowni, czy też po prostu z wieloletnim jej funkcjonowaniem na terenie gminy ${ }^{3}$.

Próbując poznać zdanie mieszkańców, poszukując napięć, konfliktów, form współpracy pomiędzy elektrownią a społecznością gminy, należy zadać mieszkańcom szereg pytań, które wcześniej zostały przygotowane na podstawie wiedzy teoretycznej. Wiedza ta, oparta przede wszystkim na źródłach zastanych, czyli literaturze, artykułach naukowych i publicystycznych, rozmaitych treściach internetowych, musi zostać przeanalizowana, a następnie zweryfikowana w trakcie badań terenowych, po których następuje etap analizy wyników badań, kolejna ich weryfikacja oraz pierwsze próby sformułowania wniosków ${ }^{4}$.

Trzeba zaznaczyć, że wstępna wiedza, wyobrażenia o terenie badań okazywały się często zupełnie odmienne od codziennej rzeczywistości i faktycznych problemów, które rozpatrywano w miarę upływu czasu, mieszkając i prowadząc badania na terenie poszczególnych sołectw. Na pewno przełomowym momentem okazał się tu podział gminy, który niemal całkowicie wpłynął na drugi etap badań i właściwie podporządkował je tematyce społecznego oporu i walki o integralność gminy ${ }^{5}$. Ponadto zakładany wcześniej zdecydowany wpływ rozbudowy elektrowni na szeroko rozumianą rzeczywistość społeczno-kulturową jej okolicy okazał się w znacznym stopniu przeszacowany, a współcześnie stosowane technologie przy tego rodzaju inwestycjach ograniczyły zakładane interakcje do kilku rodzajów powiązań, z których na pierwszym i dominującym planie znalazły się inwe-

3 Relacje społeczno-ekonomiczne z okresu budowy i dotychczasowego funkcjonowania Elektrowni Opole są tylko jednym z kontekstów przywoływanych w tekście wyników badań. Były już one opisywane w kilku pracach zbiorowych, np.: Łuszczewska 1993 i Lesiuk, Rauziński, Sołdra-Gwiżdż 2000.

4 Dodać należy, że społeczność gminy Dobrzeń Wielki wielokrotnie była już przedmiotem badań socjologicznych, których początki sięgają pierwszych lat po II wojnie światowej. Związane są one z osobą Stanisława Ossowskiego i dotyczą głównie problematyki struktury społecznej: Ossowski 1967: 251-300.

Kwestie związane ze zmianą granic gminy poruszone są w końcowej części tekstu. 
stycje związane z rozbudową bazy noclegowej dla pracowników pracujących przy budowie nowych bloków energetycznych.

Badania terenowe prowadzone były $w$ trzech etapach, poczynając od roku 2015. Pierwszy etap badań miał charakter wstępny, polegający na uściśleniu problemów badawczych, zidentyfikowaniu faktycznych zjawisk wpływających na lokalne formy ekonomii i gospodarki. Kolejne etapy, czyli badania w roku 2016 i 2017, były już solidnie osadzone w miejscowym środowisku, pokazując wyraźnie kierunki działań podejmowanych przez mieszkańców. Podkreślić trzeba, że w założeniach badawczych w żaden sposób nie została uwzględniona sytuacja związana z podziałem gminy, co więcej, była ona dla badaczy, podobnie jak dla większości mieszkańców gminy, całkowitym zaskoczeniem. Wydarzenia $\mathrm{z}$ tym związane niemal całkowicie zdominowały badania prowadzone $\mathrm{w}$ roku 2016 i 2017, ukazując z całą siłą dynamikę przemian, jakie zaczęły zachodzić pod wpływem politycznych decyzji zapadających ponad głowami mieszkańców. Nie mogło więc być mowy o prowadzeniu badań zgodnie z założeniami poczynionymi kilkanaście miesięcy wcześniej. Koniecznością i wymogiem chwili stało się uwzględnienie tego, co dla mieszkańców okazało się momentem przełomowym w ich życiu jako obywateli gminy Dobrzeń Wielki, która na ich i naszych oczach została podzielona. Nagle duża część gminy, wbrew woli większości jej mieszkańców, stała się częścią miasta Opole, w którego granicach znalazły się elektrownia oraz większość firm z nią współpracujących. W ten sposób dalsze próby badań interakcji ekonomicznych pomiędzy tymi podmiotami a społecznością gminy zostały utrudnione, a właściwie stały się, w odniesieniu do głównego tematu badań, bezproduktywne, wszak byłyby to już badania procesów zachodzących nie w gminie Dobrzeń Wielki, ale w części miasta Opole. W tej nowej i nieprzewidzianej w projekcie badań sytuacji musiały one ulec pewnej modyfikacji. I tak, po pierwsze, nie zrezygnowano z prowadzenia eksploracji terenowej i nie ograniczono się do badań na obszarze gminy w nowych, pomniejszonych granicach. Po drugie, kontynuowano badania, wprowadzając takie modyfikacje w pytaniach do mieszkańców, które uwzględniałyby ich zdanie w kwestii podziału gminy, strat i zysków dla lokalnej ekonomii oraz opinii dotyczących wydarzeń związanych ze zmianą granic i przewidywań na przyszłość. Po trzecie, tereny włączone w granice miasta Opole zostały potraktowane jako obszar, w pewnym sensie przejściowy, na którym dopiero w przyszłości można będzie zauważyć efekty zmian, zaś obecnie posiadający ciągle różnego rodzaju związki z gminą Dobrzeń Wielki.

Należy zaznaczyć, że w kręgu zainteresowań badawczych musiały znaleźć się $\mathrm{z}$ konieczności procesy związane nie tylko z rozbudową, ale i budową oraz funkcjonowaniem elektrowni, które zasadniczo zmieniły krajobraz podopolskiej wsi, a przede wszystkim rzeczywistość społeczno-kulturową gminy. Mimo że uruchomienie tej wielkiej inwestycji przemysłowej było częścią procesów modernizacyjnych, które objęły cały kraj po roku 1989, to jednak proces budowy Elektrowni Opole oparty był na modelu gospodarki z czasów PRL, przedstawianej jako ciągły 
rozwój i wykorzystywanej przez ówczesne władze jako element tak zwanej propagandy sukcesu. Można zaryzykować twierdzenie, że późniejsza decyzja o rozbudowie elektrowni przypomina pod niektórymi względami tę „hurraoptymistyczną" atmosferę towarzyszącą tego typu działaniom w peerelowskiej rzeczywistości. Związane z tym różnorakie oczekiwania mieszkańców, które nie spełniły się wraz $\mathrm{z}$ budową, a przede wszystkim wieloletnią obecnością elektrowni na terenie gminy, zostały wkrótce przeniesione na jej rozbudowę. Upatrywano w niej od początku podstawowego czynnika decydującego o rozwoju gminy. Gminy rozwijającej się i tak dużo prężniej niż większość gmin w Polsce czy Europie, między innymi dzięki podatkom uzyskiwanym od elektrowni.

Jako wielka inwestycja i gigantyczny obiekt materialny elektrownia stała się dominującym „współmieszkańcem” lokalnego świata, diametralnie modyfikującym krajobraz kulturowy, także poprzez sieć firm, przedsiębiorstw i zakładów przemysłowych, które wyrosły w jej bliskim sąsiedztwie, oraz rozkwit różnorakich działalności gospodarczych, powiązanych bezpośrednio lub pośrednio z funkcjonowaniem elektrowni, a także, przynajmniej potencjalnie, z jej rozbudową.

W ogólnie zarysowanej sieci lokalnej ekonomii teren badań jawi się jako niejednorodny, mimo sugerującej pewną jednolitość dominującej roli Elektrowni Opole. Odmienny charakter ma działalność podmiotów gospodarczych powstałych głównie z powodu współpracy z elektrownią od tych, które z tej współpracy korzystają w mniejszym stopniu lub w ogóle nie wskazują na jakiekolwiek z nią związki. Uderzający i sprzeczny z badawczą intuicją jest fakt niewielkiego rozwoju przedsiębiorczości lokalnej skierowanej głównie na korzyści płynące z samej rozbudowy, która okazała się przebiegać według innych wzorów niż te znane z czasów budowy elektrowni. Zasadnicza różnica polega w tym wypadku na tym, że większość elementów potrzebnych do budowy nowych bloków energetycznych wytwarzana jest poza obszarem gminy, czasami w innych krajach, z których są transportowane i montowane na miejscu. W takiej sytuacji można odnieść wrażenie istnienia obok siebie dwóch różnych i całkowicie odseparowanych rzeczywistości społecznych i ekonomicznych. Jedna obejmuje elektrownię wraz z terenami przyległymi, druga pozostałe obszary gminy, które z rozbudową elektrowni mają niewiele wspólnego, z ludźmi zajmującymi się swoimi sprawami, żyjącymi własnym tempem.

$\mathrm{Na}$ wspomniane zjawiska decydujący wpływ mają procesy o charakterze globalizacyjnym, polegające między innymi na możliwości przepływu technologii i jej wytworów w krótkim czasie na dużych odległościach. Często efektem tego jest wyłączenie z przebiegu realizacji inwestycji przemysłowych lokalnych środowisk na rzecz środowisk, w których koszty wytworzenia poszczególnych elementów inwestycji są niższe czy też poszukiwanie wyspecjalizowanych wykonawców w odległych nieraz o tysiące kilometrów krajach. Niska cena i zawodowa specjalizacja odgrywają tu więc kluczową rolę, co decyduje o potraktowaniu lokalnego środowiska jako mniej istotnego uczestnika realizacji inwestycji. Dotyczy to 
również kosztów związanych z zatrudnieniem, a dokładniej zjawiskiem tak zwanej taniej siły roboczej, mającym być typowym dla polskiego rynku pracy. Dziś wyspecjalizowane agencje są gotowe sprowadzić pracowników z odległych terenów kraju oraz z zagranicy wtedy, gdy koszty zatrudnienia okolicznych pracowników mogłyby okazać się za wysokie. Tak stało się między innymi przy rozbudowie elektrowni, gdzie liczną grupę stanowią na przykład robotnicy z Ukrainy. Należy dodać, że rozpoczęcie rozbudowy miało miejsce w czasie, kiedy nie występowało jeszcze zjawisko braku rąk do pracy, które zauważane jest na krajowym rynku w ostatnich latach i wiąże się z dynamicznym spadkiem bezrobocia.

W takim, zarysowanym pokrótce, kontekście prowadzono badania, spodziewając się uzyskać wyniki pozwalające na przedstawienie obrazu miejsc i ludzi oraz procesów, które zachodzą na przecięciu relacji politycznych, gospodarczych i ekonomicznych. Podstawowym zamierzeniem było uchwycenie oddolnych strategii ekonomicznych oraz ujawnienie ich powiązania z rozbudową elektrowni, a także przedstawienie swego rodzaju portretu lokalnej przedsiębiorczości, związanych z tym nadziei i rozczarowań, jak również pewnej traumy, która ujawniła się podczas badań i wynikała z politycznej decyzji o podziale gminy. Bez wątpienia są to istotne zjawiska, które w wielopoziomowy sposób wpływają na życie mieszkańców w wymiarze zarówno jednostkowym, jak i grupowym. Taki zbiorowy portret tworzony w swoistym krajobrazie społeczno-kulturowym, cechującym się mieszanką elementów wiejskich, przedmiejskich i przemysłowych, jest możliwy do uzyskania, gdy głos odda się mieszkańcom, którzy w swoich wypowiedziach $\mathrm{z}$ całą mocą ujawniają specyfikę miejsca, w jakim przyszło im żyć i pracować. Zachodzące zmiany mogą być także opisywane poprzez analizę procesów gentryfikacji i jej skutków ${ }^{6}$. Proces ten trwa w gminie nieprzerwanie, zwłaszcza od momentu budowy elektrowni, napływu nowej, zwykle lepiej wykształconej ludności, mającej wpływ na lokalną gospodarkę i jej segmenty. Konsekwencją przeobrażeń w strukturze społecznej są na przykład zmiany w układzie przestrzennym gminy, zmiany w stylu życia mieszkańców, powstanie określonych relacji pomiędzy grupami zasiedziałej ludności miejscowej i gentryfierów ${ }^{7}$. Ci ostatni często wymykają się stereotypowym poglądom na temat braku ich aktywności społeczno-obywatelskiej. Tymczasem cele bywają zbieżne z działaniami ludności rodzimej na rzecz społeczności lokalnej i jej interesami, czego wymownym przykładem była niechęć większości z nich, niezależnie od pochodzenia i przynależności etnicznej, do włączenia części gminy w obręb miasta Opole.

6 O procesach tego typu w szerszym kontekście zob. między innymi: Śpiewak 2016: 129-157.

7 Dobrze obrazuje to powstanie osiedla mieszkaniowego „Energetyk” przeznaczonego dla pracowników elektrowni, do których początkowo odnoszono się nieufnie. Z upływem czasu antagonizmy ustąpiły i wskutek różnorakich działań i procesów integracyjnych ujawniło się poczucie wspólnoty wynikającej nie tylko z miejsca zamieszkania, ale też podzielania podobnych wartości (por.: Berlińska 2000: 89-98). 
Jak wspomniano, badania były prowadzone w trzech etapach i podzielone tematycznie na części związane z konfliktami, napięciami i współpracą, obejmującymi przede wszystkim relacje zachodzące pomiędzy lokalnymi przedsięwzięciami o charakterze ekonomicznym a rozbudową Elektrowni Opole.

Tak zwaną pierwszą łopatę pod budowę nowych bloków elektrowni wbito w lutym 2014 roku (planując zakończenie inwestycji na marzec 2019 r.). Nic jeszcze wówczas nie zwiastowało jakichkolwiek zmian administracyjnych i związanych z tym napięć. Gmina postrzegana była jako bardzo zamożna i jedna z najbogatszych w Polsce. Rozbudowa elektrowni miała wzmocnić tę wyjątkowo dobrą pozycję ekonomiczną oraz zaowocować pojawieniem się związanych z nią inicjatyw gospodarczych, a powiększenie obszaru inwestycji zapowiadało w przyszłości wzrost wpływów podatkowych gwarantujących intensywny rozwój gminy. Prognozowane wpływy sprawiły, że wśród dylematów, przed którymi stała rada gminy, były nie tyle zaspokojone już w dużej mierze podstawowe potrzeby mieszkańców, ile kwestie raczej drugoplanowe, takie jak na przykład dyskusja o tym, czy wybudować w gminie basen czy aquapark. Trzeba przyznać, że niejedna gmina w Polsce chciałaby mieć tego typu problemy do rozwiązania.

W przypadku funkcjonowania oraz rozbudowy wielkiej inwestycji przemysłowej pojawiają się jednak zjawiska, które mogą powodować napięcia oraz potencjalne konflikty. Taki charakter miało już samo podjęcie decyzji o rozbudowie elektrowni niepoprzedzone szerszymi konsultacjami społecznymi. Ten brak uwzględnienia zdania mieszkańców był często podkreślany, chociaż równolegle zdawano sobie sprawę z konieczności rozbudowy, która planowana była od dawna i zapewnić miała projektowaną docelową moc elektrowni.

Gdy rozbudowa elektrowni stała się faktem, pojawiło się wiele obaw związanych z różnymi możliwymi konsekwencjami towarzyszącymi tego typu inwestycji. Punktem odniesienia dla tego typu opinii były doświadczenia mieszkańców z okresu powstawania i uruchamiania elektrowni. Wspomina się w tym przypadku zazwyczaj chaos i patologiczne zachowania na placu budowy oraz w jego otoczeniu, napływ obcych czy dewastację środowiska naturalnego. Trzeba wyraźnie podkreślić, że pamięć z tym związana obecna jest często w formie już zmitologizowanej i przekazywanej przez pokolenie będące świadkiem tych wydarzeń. Opowieści tego typu obecne ciągle w obiegu społecznym przyczyniły się do wyolbrzymienia podobnych zagrożeń przy rozbudowie elektrowni. Niepewność wielu mieszkańców gminy wzmagał uważnie obserwowany przez nich polityczny dyskurs wokół problemu rozbudowy. Zmieniające się stanowiska kolejnych władz na szczeblu państwowym dotyczące podjęcia decyzji o rozbudowie bądź jej zaniechaniu stawiały na przykład pod znakiem zapytania celowość lokalnych inicjatyw gospodarczych nakierowanych na potencjalne zyski z udziału w szeroko rozumianym procesie rozbudowy elektrowni. Kolejną kwestią, którą warto odnotować, były obawy związane z ogólnopolską dyskusją na temat budowy elektrowni atomowej i zaniechania rozwoju energetyki opartej na węglu. Niektórzy rozmówcy 
podkreślali, że chociaż rozbudowa elektrowni jest przedsięwzięciem właściwym i sprzyjającym rozwojowi gminy i Polski, to decyzja ta jest krótkowzroczna. Uważali, że to błąd, ponieważ Polska w końcu i tak będzie zmuszona do wybudowania elektrowni atomowej: „Musimy dążyć do bycia samowystarczalnymi, a bez elektrowni atomowej w pewnym momencie przestanie to być możliwe". Spotkano także opinie sugerujące, że jest to decyzja czysto polityczna i ekonomicznie nieuzasadniona, chociaż osoby pamiętające katastrofę w Czarnobylu podkreślały, że ze względów bezpieczeństwa lepiej, aby elektrownia bazowała na węglu, którego ponadto w Polsce jest pod dostatkiem.

Kolejną konsekwencją rozbudowy, związaną z zastosowaną technologią opartą na wykorzystywaniu węgla kamiennego, stała się obawa mieszkańców o zanieczyszczenie środowiska naturalnego i jego wpływ na życie i zdrowie mieszkańców. Powróciły obawy znane z czasu powstawania inwestycji, chociaż w tej kwestii wypowiedzi bywały sprzeczne. Osoby wypowiadające się na ten temat często nie ufały zapewnieniom o zastosowanych technologiach, które w żaden sposób nie będą wpływać na sytuację ekologiczną regionu. Podkreślano na przykład, że znacząco obniżył się poziom wód gruntowych, co miało mieć wpływ na upadek rolnictwa w gminie. Uważano, że elektrownia "truje” mieszkańców i zanieczyszcza okolicę. Z obserwacji niektórych osób wynika, że zwiększyła się zachorowalność ludzi w tej okolicy. Dotyczy to również gmin sąsiednich, „gdzie dym z komina opada na ziemię". Mówiono też o niekorzystnym działaniu pola magnetycznego wokół linii przesyłowych czy o możliwości powodowania astmy, nowotworów i alergii, zwłaszcza u dzieci. Mieszkańcy dostrzegali też zjawisko powstania swoistego mikroklimatu, który ma charakteryzować się zmniejszoną ilością opadów deszczu. Równocześnie nie brakowało wypowiedzi odmiennych, wskazujących na przykład na poprawę jakości powietrza wynikającą z dostępu do sieci ciepłowniczej, a co za tym idzie - likwidacji małych kotłowni, spalających niskiej jakości paliwo węglowe czy po prostu śmieci. Należy dodać, że wiele tego rodzaju opinii wiąże się z nikłą wiedzą mieszańców na temat zastosowanych w elektrowni technologii. Opinie te dotyczą zarówno dotychczasowego funkcjonowania elektrowni, jak i jej rozbudowy, która niesie z sobą jeszcze innego rodzaju obawy o otoczenie.

Od początku rozpoczęcia inwestycji mieszańcy zauważyli uciążliwości związane z rozbudową. Na pierwszym miejscu wymienia się w tym przypadku wzmożony ruch samochodowy i kolejowy, duże zanieczyszczenie powietrza i degradację dróg spowodowaną ciężkim transportem samochodowym. Z największym natężeniem zjawiska te występują w miejscowości Brzezie i jej okolicach oraz na drogach dojazdowych do elektrowni. Brzezie są ponadto wsią najbardziej narażoną na wszelkie niedogodności towarzyszące rozbudowie, jest to także jedyna miejscowość, z której wysiedlono część mieszkańców. Postępowanie to motywowane było bezpośrednim sąsiedztwem nowo budowanych chłodni, które na przykład miały ograniczać dostęp do światła słonecznego, a nawet pozbawić go część gospodarstw domowych. Prognozowano również zwiększenie poziomu hałasu 
i zapylenia. Mimo niechęci do wyprowadzki i sporów o wycenę majątku, mieszkańcy otrzymali długo negocjowane rekompensaty za opuszczone budynki.

Niezwykle istotnym i podkreślanym przez większość rozmówców problemem był niepokój przed spodziewanym napływem fali robotników z różnych części kraju i z zagranicy. Obawy te miały dwojaki charakter. Po pierwsze lękano się przybycia obcych, nieznających lokalnej specyfiki społeczno-kulturowej i z tego powodu będących potencjalnym źródłem zagrożenia. Po drugie wyobrażano je sobie w postaci wzrostu przestępczości czy nawet konfliktów na tle narodowościowym.

Tego typu obawy wynikają z doświadczeń z czasów budowy elektrowni, której konsekwencją był napływ ludności z rożnych stron kraju. Przybysze wniknęli w struktury tego terenu i zaczęli je zmieniać, ponadto widać było, że nie znali oni śląskiego stylu życia, cechującego się według miejscowej ludności spokojem, porządkiem i wysokim szacunkiem do pracy: „Widać, które domy są rdzennych mieszkańców okolicy. Są one dużo bardziej zadbane, wypielęgnowane”. Z rozmów z mieszkańcami wywnioskować można, że proces akulturacji nigdy się całkowicie nie zakończył i trwa do dzisiaj. Z ich punktu widzenia rozbudowa elektrowni może pociągnąć za sobą powtórzenie zjawiska napływu obcych. Pierwsze symptomy dostrzeżono bardzo szybko i dotyczyły one obcokrajowców, chociaż wiele obaw okazało się nieuzasadnionych:

Namnożyło się tutaj tych wszystkich Ukraińców, jak teraz rozbudowują elektrownię. Panoszą się to tu, to tam. Co prawda nie przeszkadzają jakoś bardzo, co jakiś czas tylko kogoś okradną, ale tak to chyba nie ma większych problemów (mieszkaniec Czarnowąsów).

Pełno tutaj Ukraińców się zjeżdża. Przyjeżdżają pracować przy rozbudowie i się wałęsają wszędzie. W sumie nic złego nie robią, ale już sam fakt, że są, że jest ich dużo, swoje robi (mieszkanka Dobrzenia Wielkiego).

Bardzo dużo ludzi boi się tych, którzy przyjeżdżają pracować przy elektrowni, jak teraz ją rozbudowują. Co prawda nikt nikogo nigdy nie złapał za rękę, tak przynajmniej mój tata mówił, ale obawy są. Że niby włażą do domów, kradną i inne takie. Ale czy to jakieś faktyczne zagrożenie, to że oni tutaj są? (mieszkanka Czarnowąsów).

Napływający robotnicy postrzegani są także jako konkurencja na rynku pracy, który traktuje się jako przynależny do lokalnego środowiska, czyli mający zapewniać zatrudnienie przede wszystkim ludności miejscowej:

Ludzie mogą się jeszcze bać, że pracę im zabiorą, ale prawda jest taka, że jak nie ma się kogoś z rodziny czy znajomych w elektrowni, to pracy się nie dostanie. Znajomy chciał tylko na praktyki i też mu nie pozwolili (mieszkanka Czarnowąsów).

Należy dodać, że paradoksalnie napływowi osób zainteresowanych pracą i zamieszkaniem na terenie gminy towarzyszy dostrzegalne zjawisko wyludniania się wsi. Dotyczy to przede wszystkim młodzieży, często korzystającej z kontaktów rodzinnych w Niemczech czy Holandii. Opinie o starzeniu się mieszkańców gminy potwierdzają wypowiedzi jednego z miejscowych proboszczów, który stwierdza 
zauważalny spadek dzietności, widoczny z jego perspektywy w zmniejszającej się liczbie chrztów i komunii.

Lękowi rozmówców o miejsca pracy towarzyszy przekonanie, że obcy zajmą najbardziej atrakcyjne miejsca pracy w Elektrowni Opole, postrzeganej jako bardzo rzetelny i dobry pracodawca w regionie. Jest ona również źródłem zatrudnienia dla wielu mieszkańców sąsiednich gmin i miasta Opole. Praca w elektrowni postrzegana jest przez mieszkańców gminy jako bardzo atrakcyjna. Oprócz powszechnego przekonania o stosunkowo wysokich zarobkach, jakie można tam osiągnąć, duże znaczenie ma fakt, że jest to stałe zatrudnienie w miejscu zamieszkania, zapewniające różnego rodzaju dodatki finansowe oraz perspektywę godziwej emerytury. Opiniom takim często towarzyszy przekonanie, że o pracę w elektrowni jest niezwykle trudno i zagwarantować ją mogą przede wszystkim osobiste czy rodzinne koneksje. Czasami takie opinie uzupełniane są przypuszczeniami, że w elektrowni pracują wysoko wyspecjalizowani fachowcy, którzy przyjeżdżają $\mathrm{z}$ odległych miast. Powszechnie uważa się, że pracę $\mathrm{w}$ elektrowni bardzo trudno dostać, nawet „po znajomości”. Z chwilą otrzymania tam zatrudnienia życie ludzi jednak ulega zmianie. Bardzo dobre zarobki, szkolenia, dopłaty do wypoczynku są magnesem przyciągającym pracowników, stąd też trudno spotkać osoby negatywnie wypowiadające się o zatrudnieniu tam, niezależnie od stanowiska.

Niezwykle istotny jest fakt obecnego utożsamiania przez mieszkańców gminy atrakcyjnej pracy w elektrowni z zatrudnieniem w konsorcjum firm zajmującym się jej rozbudową. Potencjalnym pracodawcą nie jest zatem elektrownia, ale wykonawca projektu rozbudowy, który zatrudnia firmy podwykonawcze wykonujące określone etapy prac. Większość mieszkańców zupełnie nie rozumie zasad funkcjonowania konsorcjum, przebiegu procesów decyzyjnych, reguł dotyczących systemów przetargowych czy procesu realizacji skomplikowanego projektu. Nie mając koniecznej wiedzy na temat współczesnych sposobów organizacji pracy przy dużej inwestycji przemysłowej, nie mogą efektywnie zabiegać o udział w kolejnych etapach procesów rozbudowy. Dostrzec też można brak wiary we własne możliwości i zasoby lokalnych firm. Stąd przekonanie o braku konkurencyjności wobec zamożniejszych polskich i zagranicznych przedsiębiorstw oraz obawa konfrontacji z nimi. Dodatkowo za zniechęcający uważa się nadmiernie skomplikowany przebieg postępowania decyzyjnego, który lokalni przedsiębiorcy potocznie i zgryźliwie nazywają „papierologią”. Nie znaczy to jednak, że w gminie nie znaleźli się inwestorzy, którzy potrafili nawiązać bezpośrednią współpracę $\mathrm{z}$ konsorcjum rozbudowującym elektrownię.

Ambiwalentność postaw wobec funkcjonowania i rozbudowy elektrowni widoczna jest wśród wielu mieszkańców gminy. Jedni poszukują korzyści, jakie bezpośrednio lub pośrednio mogliby odnieść, inni wyrażają się krytycznie i nie widzą dla siebie i gminy profitów płynących z realizacji inwestycji, co obrazują powtarzające się w swej wymowie wypowiedzi: 
Nie ma pracy. Jeśli ktoś chce zyskać stanowisko w elektrowni, to musi mieć znajomości. Wszyscy młodzi uciekają z miasta i gminy, najczęściej do Wrocławia, gdzie jest praca. Bo tam to zawsze się coś znajdzie, a tutaj to nie [...]. Dla mieszkańców to raczej nic $\mathrm{z}$ tego nie będzie. Te wszystkie spółki i inne takie przejmują stanowiska mieszkańców. A gmina? Gmina to i może ma $\mathrm{z}$ tego jakieś korzyści. Składki płacone przez elektrownię, czy coś w tym rodzaju. No i ciągną tą ciepłą wodę i ogrzewanie od elektrowni, więc zimą jest ciepło i nie trzeba się martwić (mieszkanka Dobrzenia Wielkiego).

Podatki, czyli pieniądze z elektrowni, można wydać na różnego rodzaju inwestycje, rozwój. Nie musimy korzystać z pożyczek, bardzo długo nie korzystaliśmy z funduszy Unii Europejskiej, co myślę, że było błędem. Obecnie nasz wójt dba o to. To, że jesteśmy gminą bogatszą, nie oznacza, że nie mamy z tego korzystać [...]. Następne dwa bloki są budowane. Dla nas, gminy, są to następne wpływy z podatków. Dla środowiska jednak jest to kolejne obciążenie [...]. Wprawdzie przetarg na budowę dwóch kolejnych bloków wygrały firmy spoza gminy, to te miejscowe działają jako podwykonawcy, zatrudniając tutejszych mieszkańców. Firmy miejscowe mają zaszczyt się rozwijać, a co za tym idzie - zatrudniają mieszkańców. Dzięki temu bezrobocie się zmniejsza (mieszkaniec Dobrzenia Wielkiego).

Wypowiedzi gloryfikujące i pozytywnie wartościujące obecność elektrowni na terenie gminy wielokrotnie się powtarzają:

Elektrownia bardzo wpłynęła na tę gminę. Gmina pobiera duże podatki, dzięki czemu ma pieniądze na rozwój. No i dużo ludzi dzięki niej ma pracę. Bardzo dobrze, że jest [...]. I tak już to, co miała zniszczyć, to zniszczyła, a teraz tylko zagospodarowuje resztę terenu (mieszkaniec Dobrzenia Wielkiego).

Gmina jest zasobna, nawet się mówi, że „w gminie Dobrzeń żyje się dobrze”, i to jest prawda. Dzięki tej elektrowni i tym firmom wokół to mamy z czegoś pieniądze, żeby móc się tu wszystkim zająć. Stopień bezrobocia jest tu właściwie żaden, jak ktoś nie chce pracować, to nie pracuje, a tak to dla każdego się coś znajdzie [...]. Skarb jest mieć taką elektrownię, bo stąd te wszystkie pieniądze są w gminie (mieszkaniec Świerkli).

Bywa, że przytaczaniu negatywnych bądź pozytywnych aspektów działania elektrowni i jej rozbudowy towarzyszą opinie mające charakter obojętny, często łączące się z niedostrzeganiem związków pomiędzy zasobnością gminy a elektrownią. Elektrownia jest w tym przypadku postrzegana jako jeden $\mathrm{z}$ elementów krajobrazu, który trzeba zaakceptować:

Elektrownia to tylko elektrownia, przed jej postawieniem żyło się może trochę lepiej, ale teraz też nie przeszkadza ona w normalnym funkcjonowaniu. Jeżeli ktoś się do niej przyzwyczai i dostosuje, to nie będzie problemu (mieszkanka Dobrzenia Małego).

Wzajemne zależności pomiędzy inwestycją a społecznością lokalną są racjonalizowane i oparte na potocznej wiedzy i potocznym rozumowaniu. Ich cechą są wyrażane przez mieszkańców oczekiwania i wyobrażenia:

Od momentu powstania EO gmina rozwija się lepiej. Gmina ma jakiś dochód, to jest wszystko powiązane. Na przykład pracownik przyjdzie do mnie zrobić zakupy, ja dzięki temu zarabiam, jedno drugie napędza. Jakość życia sukcesywnie się zwiększa, ale nie wygląda to tak, jak obiecywano. Na przykład obiecano, że mieszkańcy terenów przy samej elektrowni będą mieli zapewnione ogrzewanie, jednak tak się nie stało. Obiecywano, że każdy mieszkaniec będzie miał 
zapewnioną pracę, a wszyscy pracownicy są napływowi, zdarzali się nawet Szwedzi. Za dawnych czasów, gdy spółka elektrowni była jednoosobowa, może rzeczywiście spełniali te obietnice. Teraz wszystko ustało [...]. Moim zdaniem nic się nie zmieni, elektrownia dba głównie o te instytucje, które ściśle z nią współpracują. Nam, drobnym przedsiębiorcom, zysk mogą zapewnić pracownicy, którzy zrobią u nas zakupy. Jest to bez znaczenia (mieszkaniec Brzezi).

Dostrzegalne są opinie, że rozbudowa elektrowni niewiele zmieni. Oczekuje się licznych trudności, a od władz gminy żąda większego zainteresowania się ochroną i losem stałych mieszkańców. Stąd pogląd, że spółka PGE wpływa na lokalne władze, nie realizując obietnic, do których, przejmując Elektrownię Opole, powinna być zobowiązana. Chodzi tu na przykład o rozwój sieci ciepłowniczej, obniżki cen energii elektrycznej, a nawet wypracowanie takiego systemu kształcenia miejscowej młodzieży, który pozwoliłby jej na pracę i objęcie stanowisk w elektrowni. Należy zaznaczyć, że są to wyobrażenia wynikające z postrzegania elektrowni jako opiekuna, który z racji zlokalizowania w gminie zobowiązany ma być do wspierania lokalnej społeczności. $\mathrm{Z}$ tego powodu bardzo negatywnie zostały ocenione zmiany w usytuowaniu dyrekcji elektrowni:

My mamy elektrownię, ale podatki idą do Bełchatowa. Bełchatów tu jest naszą dyrekcją, a to jest niedobrze. No i to tak jest, że są firmy z zewnątrz, jest dużo takich innych firm, które tu mają, smród nam zostawiają, a oni (Bełchatów) kasują, bo oni są dyrekcją (mieszkaniec Świerkli).

Powstanie Grupy Kapitałowej Polskiej Grupy Energetycznej (PGE), największego w Polsce przedsiębiorstwa sektora elektroenergetycznego, prowadzącego działalność związaną z wydobyciem węgla brunatnego, wytwarzaniem energii elektrycznej z paliw kopalnych, jak również z odnawialnych źródeł energii oraz dystrybucją i sprzedażą energii elektrycznej, sprawiło, że Elektrownia Opole stała się jednym $\mathrm{z}$ wielu podmiotów, które wchodzą w skład tej grupy. Fakt ten spowodował, że ośrodki decyzyjne zajmujące się relacjami pomiędzy przedsiębiorstwami a społecznością lokalną znalazły się poza regionem funkcjonowania i oddziaływania elektrowni. Grupa Kapitałowa PGE deklaruje, że jest organizacją odpowiedzialną społecznie i świadomą swojego wpływu na otoczenie i dlatego w swoich działaniach koncentruje się na ograniczaniu wpływu na środowisko, działaniu na podstawie zasad etycznych oraz zaangażowaniu na rzecz lokalnych społeczności, zapewniając zrównoważony rozwój biznesu. W przypadku Elektrowni Opole najważniejszym przejawem takich działań są organizowane od 2008 roku tak zwane Dni Otwarte, polegające głównie na prowadzeniu działalności edukacyjnej przybliżającej procesy technologiczne towarzyszące produkcji energii elektrycznej, rolę Elektrowni Opole w systemie elektroenergetycznym kraju czy zasady bezpieczeństwa obowiązujące na terenie zakładu i kolejne etapy rozbudowy. Tego typu relacje pomiędzy elektrownią a miejscową społecznością nie przypominają już współpracy znanej z przeszłości, gdy elektrownia była jednostką samodzielną, wspierającą bezpośrednio inicjatywy lokalne. Mocno ograniczony zakres takiej współpracy wpływa więc na sposób postrzegania elektrowni. Na podstawie opinii 
mieszkańców można stwierdzić, że ze „współmieszkańca” lokalnego świata stała się ona raczej wyizolowanym, odrębnym bytem. Industrialny twór, jakim jest elektrownia, widoczny jest niemal z każdego miejsca w gminie, całkowicie dominuje nad miejscowym krajobrazem. Mieszkańcy zdołali go jednak oswoić i zaakceptować, zdając sobie sprawę z korzyści, jakie im przynosi. Tymczasem jedna decyzja polityczna przekreśliła istniejący dotychczas stan rzeczy.

W marcu 2016 roku mieszkańcy gminy Dobrzeń Wielki przeczytali w gazecie „Nowa Trybuna Opolska”, że prezydent miasta Opole przekazał na szczebel rządowy wniosek o powiększenie miasta Opole o wybrane tereny sąsiadujących z nim gmin. Dla mieszkańców gminy Dobrzeń Wielki była to decyzja oznaczająca utratę kilku sołectw, w tym najważniejszego $\mathrm{z}$ ekonomicznego punktu widzenia sołectwa Brzezie, na którego terenie działa Elektrownia Opole oraz większość dużych przedsiębiorstw. Rozwój gminy, dalekosiężne plany ekonomiczne stanęły pod znakiem zapytania. Wydarzenie to zdominowało życie mieszkańców gminy. Wielu z nich uważa, że strategia władz miasta Opole ma na celu zawłaszczenie przestrzeni gminy i nosi znamiona instytucjonalnej interwencji zmierzającej do takiej redystrybucji dóbr, która zuboży mieszkańców, że motywami takich działań nie jest: konieczność rozwoju terytorialnego miasta, dobro większych grup społecznych, ale zwykły „zamach na kasę”. Nie bez znaczenia jest także odczuwana przez mieszkańców i władze gminy chęć rozbicia sprawnie funkcjonującej społeczności lokalnej, której integralną częścią jest rodzima ludność śląska i mniejszość niemiecka. Społeczność ta poniosła już duże koszty (materialne, społeczne, środowiskowe) związane $\mathrm{z}$ budową wielkiej inwestycji na jej terenie, a gdy zaczęła się prężnie rozwijać, korzystając ze środków płynących z tej inwestycji, ma zostać ich pozbawiona. Nie dziwi więc, że władze gminy przy pełnym, niemal stuprocentowym poparciu miejscowej społeczności, podjęły szereg działań zmierzających do obrony terytorialnego statusu gminy i respektowania praw obywatelskich jej mieszkańców. Sytuacja ta spowodowała spontaniczną, oddolną społeczną reakcję sprzeciwu, która przybrała bardzo różne formy: manifestacje, pikiety, blokady dróg i urzędów, protesty w skali ogólnokrajowej. W krajobrazie gminy niemal na stałe zagościły flagi, transparenty, plakaty informujące o poglądach mieszkańców i ich sprzeciwie wobec decyzji podejmowanych za ich plecami.

Tak dynamicznie rozwijający się konflikt stworzył konieczność spojrzenia na podejmowane dotychczas badania z zupełnie innej perspektywy. Rozbudowa elektrowni rzeczywiście zrodziła problemy, które można rozpatrywać w triadzie konflikt - napięcie - współpraca, tyle że problemy z tym związane przeniosły się na inny poziom. Funkcjonowanie i rozbudowa elektrowni zaczęły być rozgrywane pomiędzy władzami województwa opolskiego i miasta Opole, rządem a społecznością, na której terenie jest ona osadzona. Pomimo podjętej już na szczeblu ministerialnym decyzji o podziale gminy, w roku 2016 nie słabły protesty mieszkańców, którzy ciągle poszukiwali korzystnych dla siebie rozwiązań. Dzisiaj, gdy gmina funkcjonuje już w nowych, pomniejszonych granicach, a jej fundusze zu- 
bożały, opór nie jest tak jednoznaczny, lecz ciągle obecny. Rodzą się kolejne pytania o przyszłość gminy, jej przetrwanie jako odrębnej jednostki administracyjnej, jakość życia i możliwość podejmowania działalności gospodarczej w nowych warunkach.

Należy dodać, że podział administracyjny gminy można rozpatrywać w co najmniej dwóch wymiarach: ekonomicznym i społecznym, przy czym nie jest możliwe ich jednoznaczne rozdzielenie. Nie ulega wątpliwości, że podział zrujnował finansowe podstawy funkcjonowania gminy jako podmiotu gospodarczego. Już w 2016 roku z budżetu ubyło około 55\% dotychczasowych wpływów. Długofalowe plany rozwoju nie mogą również uwzględnić spodziewanych zysków z rozbudowy elektrowni wynikających na przykład z powstania nowych bloków energetycznych, chłodni i innych obiektów, od których usytuowania elektrownia będzie odprowadzać stosowny podatek właścicielowi gruntów (obecnie miastu Opole). Problemy ekonomiczne gminy $\mathrm{w}$ jej nowych granicach z konieczności muszą zostać rozwiązane poprzez podjęcie konkretnych działań przez lokalne władze. Poszukuje się więc dodatkowych dochodów, planując sprzedaż części terenów gminy pod zabudowę mieszkaniową oraz infrastruktury (np. wodociągów i kanalizacji) będącej własnością gminy Dobrzeń Wielki i znajdującej się obecnie w granicach miasta Opole. Podejmowane są również działania na rzecz odzyskania niektórych terenów gminy, które mogłyby zostać przeznaczone na tereny inwestycyjne. Kluczem do powodzenia tych działań jest efektywna restrukturyzacja gminy uwzględniająca w równej mierze aspekt ekonomiczny i społeczny. Jeszcze w 2016 roku mieszkańcy za swój sukces uważali zgodne współżycie i współpracę ludności rodzimej i napływowej. Jedność ta przejawiała się w aktywności kulturalnej, edukacyjnej, przedsięwzięciach na rzecz jakości życia we wspólnej przestrzeni, a nawet działalności politycznej. Tymczasem masowe protesty przeciw podziałowi gminy, które podkreślały jedność mieszkańców, paradoksalnie ujawniły różnice. Zwarta tkanka społeczna uległa pęknięciu, pojawiły się sprzeczne opinie dotyczące stosunku do celowości zachodzących zmian, co przejawiało się na przykład w dyskusjach na temat poprawy/pogorszenia jakości życia w nowych granicach administracyjnych Opola i okrojonej terytorialnie gminy Dobrzeń Wielki. W ten sposób rozbudowa Elektrowni Opole postrzegana wcześniej jako inwestycja prorozwojowa stała się ostatecznie przyczyną kłopotów gminy, która będąc do niedawna jedną z najbogatszych w Polsce - dziś walczy o przetrwanie.

\section{Bibliografia}

\section{Berlińska D.}

2000 Integracja społeczna mieszkańców osiedla „Energetyk” z zasiedziała ludnościa Dobrzenia Wielkiego, w: W. Lesiuk, R. Rauziński, T. Sołdra-Gwiżdż (red.), Między przeszłością a przyszłością. Elektrownia „Opole” jako czynnik zmiany społecznej, Opole 2000, s. 89-98. 
Hann Ch., Hart K.

2015 Antropologia ekonomiczna. Historia, etnografia, krytyka, przeł. I. Kołbon, Poznań. Lesiuk W., Rauziński R., Sołdra-Gwiżdż T. (red.)

2000 Między przeszłością a przyszłością. Elektrownia „Opole” jako czynnik zmiany społecznej, Opole.

Łuszczewska B. (red.)

1993 Elektrownia „Opole” a środowisko społeczne, Opole.

Ossowski S.

1967 Zagadnienia więzi regionalnej i więzi narodowej na Śląsku Opolskim, w: S. Ossowski, Dzieła. T. 3: Z zagadnień psychologii społecznej, s. 251-300.

Śpiewak R.

2016 Wiejska gentryfikacja. Definicja, znaczenie i skutki procesu, w: M. Halamska, S. Michalska, R. Śpiewak (red.), Studia nad strukturą społeczną wiejskiej Polski, T. 1, Warszawa 2016, s. 129-157. 